\title{
The Influence of a Humectant on the Retention by Humans of Solanesol from Cigarette Smoke (Part 2, Glycerin)*
}

\author{
by \\ Serban C. Moldoveanu and William M. Coleman III \\ R.J. Reynolds Tobacco Co., 950 Reynolds Blvd., Winston-Salem, NC 27105 USA
}

\section{SUMMARY}

Two common humectants are used as additives in the cigarette manufacturing process, propylene glycol (PG) and glycerin. The humectants may influence the deposition of cigarette smoke in the human respiratory tract by affecting the hygroscopic properties and growth of smoke particles. This study examines the influence of glycerin addition on the retention of solanesol by smokers. The influence of PG addition has been previously reported (7). The first cigarette used in the study (control) was a commercially available brand containing no additives in the blend (with a measured level of glycerin of $0.19 \%$ ). The other cigarette (test) had an identical tobacco blend to the control, but had $2.3 \%$ added glycerin. The construction of the cigarette with $2.3 \%$ glycerin (test) was selected to match as closely as possible the 'tar' (as measured by Federal Trade Commission regimen), pressure drop (open and closed), and nicotine level of the commercial cigarette (control). Twelve smokers evaluated both products. The sample collection was performed using three cigarettes smoked within one hour. Each human subject smoked the control cigarette and then the test cigarette in two separate sessions. The exhaled smoke was collected using a vacuum assisted procedure designed to avoid strain in exhaling, and solanesol was analyzed using an high performance liquid chromatography (HPLC) technique. The cigarette butts from the smokers were collected and also analyzed for solanesol. The results obtained for the cigarette butts from the smokers were used to calculate the level of solanesol in the smoke delivered to the human subject, based on calibration curves. These curves were generated separately by analyzing the solanesol in smoke and in the cigarette butts obtained by machine smoking under different puffing regimes. Knowing the levels of delivered amount of solanesol and that in the exhaled smoke it was possible to calculate the retention of this compound from mainstream smoke for the two cigarette types. The amount of solanesol retained by the smoker (per cigarette) was on average $314.8 \mu \mathrm{g} / \mathrm{cig}$ with $18.9 \%$ relative standard deviation for the commercial cigarette, and $302.6 \mu \mathrm{g} / \mathrm{cig}$ with $20.3 \%$ relative standard deviation for the cigarette with $2.3 \%$ added glycerin. The retention $\%$ of solanesol from the commercial cigarette showed an average of $69.5 \%$ with $9.4 \%$ relative standard deviation, and the cigarette with $2.3 \%$ added glycerin showed an average retention of $69.4 \%$ with $10.5 \%$ relative standard deviation. Applying the paired $t$-test to the data it was found that there were no significant differences in the retention amount of solanesol, or in the retention $\%$ of solanesol for the two cigarettes. No correlation was found between the amount of solanesol delivered to the smoker (in $\mu \mathrm{g} / \mathrm{cig}$ ) and the solanesol retention $\%$ by the smoker. [Beitr. Tabakforsch. Int. 23 (2009) 377-383]

\section{ZUSAMMENFASSUNG}

Zwei übliche Feuchthaltemittel, und zwar Propylenglykol (PG) und Glycerin, werden bei der Zigarettenherstellung als Additive verwendet. Die Feuchthaltemittel können die Ablagerung von Zigarettenrauch im Atmungstrakt von Rauchern beeinflussen, indem sie die hygroskopischen Eigenschaften und die Größe der Rauchpartikel verändern. Diese Studie untersucht den Einfluss der Glycerinzugabe auf die Solanesolretention bei Rauchern. Über den Einfluss der PG-Zugabe wurde bereits in der Literatur berichtet (7). Bei der ersten Zigarette, die in der Untersuchung als Kontrollzigarette verwendet wurde, handelte es sich um eine handelsübliche Zigarettenmarke ohne Zusatzstoffe in der Tabakmischung (und einem gemessenen Glycerinanteil von 0,19\%). Die andere Zigarette (Testzigarette) bestand aus einer identischen Tabakmischung wie die Kontrollzigarette, hatte jedoch zusätzlich einen Anteil von 2,3\% Glycerin. Die Zigarette mit einem 2,3\%-gen Glycerinanteil (Testzigarette) 
wurde derart hergestellt, dass der Kondensatausbeute [gemessen unter den Abrauchbedingungen der „Federal Trade Commission" (FTC)], der Zugwiderstand (offen und geschlossen) und die Nikotinausbeute möglichest genau der handelsüblichen Kontrollzigarette entsprach. Zwölf Raucher wurden für die Evaluation beider Produkte herangezogen, wobei drei Zigaretten pro Stunde geraucht wurden. Jeder Raucher rauchte zunächst die Kontrollzigarette und dann in zwei getrennten Sitzungen die Testzigarette. Der exhalierte Rauch wurde mit einem Vakuum-unterstützten Verfahren gesammelt, um einen Widerstand beim Exhalieren zu vermeiden, und das Solanesol wurde mittels Hochdruck-Flüssigkeitschromatographie (HPLC) bestimmt. Die von den Rauchern zurückgelassenen Zigarettenstummel wurden gesammelt und ebenfalls auf ihren Solanesolgehalt untersucht. Das Solanesol in den Zigarettenstummeln der Raucher wurde dazu herangezogen, um die aufgenommene Solanesolmenge auf der Basis von Eichkurven zu berechnen. Diese Kurven wurden separat generiert, indem die Solanesolgehalte im Rauch und auch in den Zigarettenstummeln analysiert wurden, die durch maschinelles Abrauchen unter verschiedenen Abrauchbedingungen erhalten wurden. Weil die Solanesolmenge, die an die Raucher abgegeben wurde und die exhalierten Mengen bekannt waren, war es möglich die Retention dieser Substanz beim Rauchen der beiden verschiedenen Zigaretten zu berechnen. Die Menge an reteniertem Solanesol (pro Zigarette) betrug durchschnittlich $314,8 \mu \mathrm{g}$ mit einer relativen Standardabweichung von $18,9 \%$ bei der handelsüblichen Zigarette und 302,6 $\mu \mathrm{g}$ (20,3\%) bei der Zigarette mit einer 2,3\%-gen Glycerinzugabe. Die prozentuale Retention von Solanesol betrug bei der handelsüblichen Zigarette durchschnittlich $69,5 \%$ bei einer Standardabweichung von 9,4\%, bei den Zigaretten mit einer 2,3\%-gen Glycerinzugabe betrug die prozentuale Retention $69,4 \%$ bei einer Standardabweichung von 10,5\%. Die statische Auswertung der Daten ( $t$-test) zeigte, dass zwischen den beiden untersuchten Zigaretten keine signifikanten Unterschiede in der Menge des aufgenommenen Solanesols und der prozentualen Retention bestanden. Zwischen der Solanesolmenge, die an die Raucher abgegeben wurde (in $\mu \mathrm{g} /$ Zigarette) und den Werten der prozentualen Retention des Solanesols bei Rauchern konnte keine Korrelation festgestellt werden. [Beitr. Tabakforsch. Int. 23 (2009) 377-383]

\section{RESUME}

Les deux humectants communs le propylèneglycol (PG) et la glycerine sont utilisés comme additives dans la fabrication des cigarettes. Les humectants peuvent influencer la déposition de la fumée de cigarette dans le système respiratoire de l'homme en affectant les propriétés hygroscopiques et la taille des particules de la fumée. Cette étude examine l'influence de l'apport de la glycerine sur la rétention du solanesol chez le fumeur. L'influence de l'apport du PG au mélange du tabac a déjà été présentée dans la littérature (7). La cigarette utilisée comme contrôle est disponible sur le marché et ne contient pas d'additives dans le mélange (ayant un taux de $0,19 \%$ de la glycerine). La cigarette utilisée comme test est fabriquée d'un mélange identique de tabac avec un apport de 2,3\% de la glycerine.
La fabriquation de la cigarette utilisée comme test a été choisie de façon à correspondre le mieux à la cigarette contrôle pour le taux de goudron [mesuré selon les méthodes normalisée de la FTC, (Federal Trade Commission)], la résistance au tirage (ouverte et fermée), et le taux de la nicotine. Les trois types de cigarettes évaluées ont été fumés par dix fumeurs, chacun fumant trois cigarettes par heure. La fumée exhalée a été échantillonnée à l'aide d'une technique sous vide pour éviter une trop grande résistance durant l'exhalation de la fumée. Le solanésol a été analysé par une technique de chromatographie en phase liquide à haute performance (HPLC). Les mégots de cigarette ont été collectés et ensuite également dosé pour leur teneur en solanésol. Ces résultats ont été utilisés pour calculer le taux de solanésol délivré aux fumeurs, basé sur des courbes de calibrage. Ces courbes ont été générées séparément en dosant la teneur en solanésol dans la fumée et dans les mégots de cigarette obtenus par le fumage par machine sous les conditions différentes. La rétention du solanésol et le pourcentage de rétention à partir de la fumée principale des deux cigarettes différentes ont été calculé à partir du taux de solanésol délivré au fumeur et les concentrations de solanésol exhalé. Le taux de solanésol retenu par le fumeur est au moyen $314,8 \mu \mathrm{g} / \mathrm{cig}$ avec un écart type de $18,9 \%$ pour la cigarette commerciale et de 302,6 $\mu \mathrm{g} / \mathrm{cig}$ avec un écart type de $20,3 \%$ pour la cigarette avec apport de $2,3 \%$ de glycerine. Le pourcentage de rétention du solanésol de la cigarette commerciale est de $69,5 \%$ avec un écart type de $9,4 \%$, la cigarette avec un apport de glycerine de 2,3\% a une rétention moyenne de $69,4 \%$ avec un écart type relatif de $10,5 \%$. L'analyse statistique ( $t$-test) des données révèle que le taux de solanésol retenu et le pourcentage de rétention ne sont pas statistiquement différents. Il n'y a pas de corrélation entre le taux de solanésol délivré au fumeur $(\mu \mathrm{g} /$ cigarette) et le pourcentage de rétention chez le fumeur. [Beitr. Tabakforsch. Int. 23 (2009) 377-383]

\section{INTRODUCTION}

Solanesol is present in tobacco and in cigarette smoke, and has been considered as a marker for the particulate phase of environmental tobacco smoke (ETS) (1-3). The compound also has been used as a marker for mainstream smoke particulate matter (1). Several studies reported the retention by smokers of solanesol from ETS (4) and from mainstream cigarette smoke $(5-10)$. The influence of humectants in cigarettes on the retention of particulate matter is also a subject of interest. These humectants could influence the hygroscopic properties and growth of smoke particles and therefore the deposition of cigarette smoke particles in the human respiratory tract $(11,12)$. Therefore the monitoring of the retention of solanesol from cigarettes with different humectant levels may provide some insight regarding the effect of humectants on smoke retention. The retention of solanesol from the smoke of a cigarette with no added humectant and with the addition of 3\% propylene glycol (PG) has been recently evaluated (13). It was reported (13) that a commercial cigarette with no additives showed an average retention of solanesol of $72.5 \%$ (with $11.7 \%$ relative standard deviation), and a cigarette closely matched 
Table 1. Description of tested cigarettes (Control: no additives, $0.19 \%$ glycerin; Test same blend as Control with $2.3 \%$ glycerin)

\begin{tabular}{lcc}
\hline Descriptor & Control & Test \\
\hline FTC 'tar' (mg/cig) & 9.8 & 10.5 \\
Cigarette length (mm) & 83 & 83 \\
Filter length (mm) & 27 & 27 \\
Filter ventilation (\%) & 29 & 29 \\
Blend type & American & American \\
Nicotine (mg/cig) & 0.92 & 0.89 \\
CO (mg/cig) & 10.4 & 10.6 \\
Smoke PG (mg/cig) & $<0.04$ & $<0.04$ \\
Smoke glycerin (mg/cig) & 0.17 & 1.17 \\
\hline
\end{tabular}

but with an addition of $3 \% \mathrm{PG}$ showed an average retention of $70.8 \%$ (with $14.5 \%$ relative standard deviation).

Besides PG, another common humectant is glycerin. Further investigation was performed in the present study on the influence on solanesol retention of adding glycerin to the tobacco blend. The initial level of glycerin on a commercial cigarette with no additives in the blend (control) was measured to be $0.19 \%$. A cigarette having the same tobacco blend as the control, but with a $2.3 \%$ addition of glycerin (test), was used as a second product to be evaluated. The level of glycerin on test the cigarette was selected to be in the range commonly used on other commercial brands. The control and the test cigarettes were evaluated on the same twelve smokers. All volunteers smoked in a familiar environment (office) with as little change as possible from typical smoking conditions and with no control on the inhalation or exhalation patterns. The solanesol level delivered to the smoker was calculated based on the solanesol in the cigarette butts from the smokers, using calibration curves obtained in advance.

\section{EXPERIMENTAL}

The description of the cigarettes tested in this study is given in Table 1. The retention of solanesol was measured after finding the levels of solanesol in the smoke exhaled and in the smoke delivered to each human subject. For this purpose the solanesol from the pads used for smoke collection (no solanesol is expected in the vapor phase smoke) and from $1 \mathrm{~cm}$ cut portion of the cigarette butts was performed by a high performance liquid chromatography (HPLC) procedure.

The experimental part of this study consists of several steps, which include: 1) collection of solanesol on Cambridge pads from the mainstream cigarette smoke obtained with a smoking machine using four different smoking regimes; the cigarette butts of the smoked cigarettes were retained for further solanesol analysis, 2) collection of solanesol from the exhaled cigarette smoke; the cigarette butts of the cigarettes smoked by humans were also retained for solanesol analysis, 3) measurement of solanesol using an HPLC method in the pads and in $1 \mathrm{~cm}$ cut portion of the cigarette butts, and 4) calculation of the results. Each of these steps will be discussed in detail in sections that follow.

\section{Collection of samples from smoking machine}

Machine smoking was performed under various regimes and the smoke was collected from five cigarettes on a single Cambridge pad. The smoking was performed on a Borgwaldt rotary machine RM20/CSR (Schnackenburgallee 15, D-22525). The smoking regimens included: $35 \mathrm{~mL}$ puff volume, a puff duration of $1.5 \mathrm{sec}$ and each puff taken at $75 \mathrm{sec}$ interval (indicated as 35/75 conditions, average flow rate $23.33 \mathrm{~mL} / \mathrm{sec}$ ), $50 \mathrm{~mL}$ puff volume, a puff duration of $2 \mathrm{sec}$ and each puff taken at $30 \mathrm{sec}$ interval (indicated as 50/30 conditions, average flow rate 25 $\mathrm{mL} / \mathrm{sec}$ ), $55 \mathrm{~mL}$ puff volume, a puff duration of $2 \mathrm{sec}$ and each puff taken at $80 \mathrm{sec}$ interval (indicated as 55/80 conditions, average flow rate $27.50 \mathrm{~mL} / \mathrm{sec}$ ), and $45 \mathrm{~mL}$ puff volume, a puff duration of $1.5 \mathrm{sec}$ and each puff taken at $40 \mathrm{sec}$ interval (indicated as 45/40 conditions, average flow rate $30.00 \mathrm{~mL} / \mathrm{sec}$ ). This variety of smoking regimes was selected in order to include a range of flow rates through the cigarette filter that covers, at least in part, the flow rates similar to those measured in human smoking (14).

The cigarette butts from the machine smoked cigarettes were also collected for the analysis of solanesol content. The butts were cut at $1 \mathrm{~cm}$ length from the mouth end, and this portion was used for the analysis of solanesol. The length of the cut portion of the cigarette butt was measured to ensure that the length was precisely $1 \mathrm{~cm}$. A correction factor was applied if a small difference of the cut length was noticed.

\section{Exhaled smoke collection}

The collection of the exhaled smoke was done using a simple device schematically shown in Figure 1. The device consisted of a $92 \mathrm{~mm}$ Cambridge pad holder and a pad having at one opening a replaceable mouth piece, and the other opening connected to a diaphragm vacuum pump, which can aspirate $2.2 \mathrm{~m}^{3} / \mathrm{h}$ (Vacuubrand GMBH, Wert-

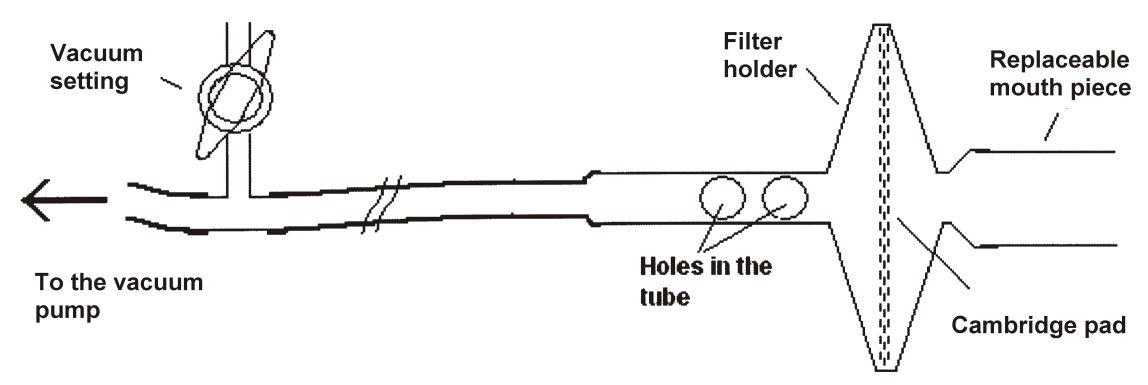

Figure 1. Device for the collection of exhaled cigarette smoke 
Table 2. Dependence lines between solanesol in smoke vs. solanesol in $1 \mathrm{~cm}$ cut of the cigarette butt

\begin{tabular}{l|c|c}
\hline Cigarette & Equation & $R^{2}$ \\
\hline Control $(0.19 \%$ glycerin) & $y=4.6606 x+17.497$ & 0.9713 \\
Test $(2.30 \%$ glycerin) & $y=4.4749 x+29.711$ & 0.9606 \\
\hline
\end{tabular}

heim, Germany). Through the pad and the connecting tubing, the pump achieved about $250 \mathrm{~mL} / \mathrm{sec}$ flow. The tube connecting the pad holder to the pump had two large holes to the exterior, which can be covered with two fingertips. When no smoke was exhaled, the holes in the tube to the vacuum pump were kept open such that surrounding air was aspirated by the pump without passing through the Cambridge filter. During exhalation of smoke, the smoker exhales the smoke through the replaceable mouth piece. At the same time the two holes in the tube were covered with two fingertips, such that the exhaled smoke was aspirated through the Cambridge pad. This allowed the exhaled smoke to be collected on the pad, without additional effort on the smoker. Considerable effort would be necessary otherwise to overcome the flow resistance of the Cambridge pad. The device shown in Figure 1 was used by twelve human subjects. A small amount of smoke potentially lost via nose-breathing was neglected. Three cigarettes were smoked for each trial within one hour, and the exhaled smoke was collected on the same pad. The smoking of the three test cigarettes and that of the three controls was performed in separate sessions (by the same smoker) within one day. All volunteers smoked in a familiar environment (office) with as little change as possible from typical smoking conditions. The cigarette butts from the smokers were retained for solanesol analysis that was performed on $1 \mathrm{~cm}$ cut from the mouth end of the cigarette.

\section{HPLC analysis}

The analysis for solanesol in the particulate phase smoke collected on pads or on the cut portion of the cigarette butts was performed using an HPLC procedure reported in the literature (7). The procedure started by extracting the pads or the cut portion of the cigarette butt with $20 \mathrm{~mL} n$ heptane containing $50 \mu \mathrm{g} / \mathrm{mL}$ pyrene (used as a chromatographic standard). A small volume of this solution $(1-1.5 \mathrm{~mL})$ was transferred in an LC vial and analyzed by HPLC using UV detection at $210 \mathrm{~nm}$, on an Agilent instrument (1050 HPLC with a diode array detector Agilent, Wilmington, DE 19808), equipped with a Spherisorb $5 \mu$ ODS (2) column $250 \times 4.6 \mathrm{~mm}$ (Phenomenex, Torrance, CA 90501-1430), and with an injection volume of $20 \mu \mathrm{L}$. The separation was performed in gradient conditions.

\section{Calculation of the results}

Quantitation of solanesol was performed using a calibration curve relating the peak area from the chromatogram and the solution concentration. For this purpose, ten standards with concentrations between $5 \mu \mathrm{g} / \mathrm{mL}$ and $300 \mu \mathrm{g} / \mathrm{mL}$ solanesol (Aldrich/Sigma, Saint Louis, MO 63178-9916) were prepared in heptane and analyzed by the previously described HPLC procedure. Each solution also contained the chromatographic standard (pyrene $50 \mu \mathrm{g} / \mathrm{mL}$ ), but the pyrene peak was used only to verify the reproducibility of the chromatography and not for normalizing solanesol peak areas. The calibration curve for solanesol quantitation was linear with $R^{2}=0.9997$, and the line intercept was zero.

\section{RESULTS AND DISCUSSION}

The analysis of solanesol was done initially for machine smoked cigarettes using different puffing conditions. At the same time with the analysis of the smoke pads, the cut portions of the cigarette butts were analyzed. Correlation charts between the level of solanesol in smoke as a function of the level in the cigarette butts were obtained. After this part of the study had been completed, the human subjects smoked the cigarettes and the exhaled smoke was collected as previously described and analyzed for solanesol. The cigarette butts from each smoker were collected and the solanesol from $1 \mathrm{~cm}$ cut portions were analyzed. Using previously generated charts, the level of solanesol in the cigarette smoke delivered to the human subject was calculated based on the measured level of solanesol in the cigarette butt from the smoker. The level of solanesol in exhaled smoke was then compared with that in the smoke delivered to the human subject.

The amount of solanesol retained by the smoker can be calculated from the following difference:

$$
\begin{aligned}
\text { Retention amount }(\mu \mathrm{g} / \mathrm{cig})= & \text { Delivered level } \\
& - \text { Exhaled level }
\end{aligned}
$$

The retention efficiencies (\%) can also be calculated for each smoker using the expression:

$$
\text { Retention } \%=100 \cdot\left[1-\frac{\text { Exhaleded level }}{\text { Delivered level }}\right]
$$

Generation of the correlation charts between the level of solanesol on the pad and in the cigarette butt for machine smoked cigarettes

In order to determine the amount of solanesol in the delivered smoke, the regression lines between the level of solanesol in smoke as a function of solanesol in $1 \mathrm{~cm}$ cut portion of the cigarette butts were generated. The dependence curves for each of the evaluated cigarettes are given in Table 2.

A linear dependence has been previously reported between the nicotine level in the cigarette butt and that collected on a Cambridge pad $(14,15)$. Other studies $(16)$ have shown that a linear dependence is also maintained between the nicotine level in the cigarette butt and the level of other compounds from smoke, such as aldehydes and ketones. Also, linear dependencies have been observed between the level of solanesol in the cigarette butt, and compounds in the mainstream smoke such as 4-(methylnitrosamino)-1-(3pyridyl)-1-butanone (NNK), $N$-nitrosonornicotine (NNN), carbon monoxide, isoprene, ethylene and acetaldehyde (17). The linear dependence between the solanesol in the 
Table 3. The levels of solanesol in $\mu \mathrm{g} / \mathrm{cig}$ in exhaled smoke for cigarettes evaluated in this study (Control: no additives, $0.19 \%$ glycerin; Test same blend as Control with $2.3 \%$ glycerin)

\begin{tabular}{l|c|c}
\hline Smoker $^{\text {a }}$ & $\begin{array}{c}\text { Control } \\
\mu \mathrm{g} / \mathrm{cig}\end{array}$ & $\begin{array}{c}\text { Test } \\
\mu \mathrm{g} / \mathrm{cig}\end{array}$ \\
\hline 1 & 143.5 & 144.3 \\
2 & 85.1 & 81.9 \\
3 & 162.6 & 157.3 \\
4 & 180.7 & 164.9 \\
5 & 143.7 & 144.3 \\
6 & 85.1 & 82.0 \\
7 & 162.3 & 156.7 \\
8 & 181.1 & 166.1 \\
9 & 154.3 & 143.1 \\
10 & 102.8 & 100.5 \\
11 & 155.2 & 144.0 \\
12 & 96.7 & 100.3 \\
\hline
\end{tabular}

a The same human subject smoked the cigarette with no glycerin and the one with $2.3 \%$ glycerin.

Table 4. The calculated levels of solanesol in $\mu \mathrm{g} / \mathrm{cig}$ in the delivered smoke (Control: no additives, $0.19 \%$ glycerin; Test same blend as Control with $2.3 \%$ glycerin)

\begin{tabular}{l|c|c}
\hline Smoker & $\begin{array}{r}\text { Control } \\
\mu \mathrm{g} / \mathrm{cig}\end{array}$ & $\begin{array}{c}\text { Test } \\
\mu \mathrm{g} / \mathrm{cig}\end{array}$ \\
\hline 1 & 428.1 & 434.6 \\
2 & 359.9 & 381.6 \\
3 & 481.8 & 470.1 \\
4 & 575.3 & 555.4 \\
5 & 386.4 & 389.4 \\
6 & 363.2 & 379.6 \\
7 & 483.7 & 471.1 \\
8 & 579.8 & 558.3 \\
9 & 387.5 & 347.2 \\
10 & 456.3 & 442.0 \\
11 & 432.8 & 348.3 \\
12 & 495.4 & 439.6 \\
\hline
\end{tabular}

cigarette butt ( $1 \mathrm{~cm}$ cut) and the solanesol in mainstream smoke (as collected on a Cambridge pad) was also demonstrated in a previous paper (7).

\section{Calculation of the retention of solanesol from the evaluated cigarettes}

The levels of solanesol in the exhaled smoke as obtained from the analysis of the Cambridge pads used for the collection of smoke from three cigarettes for each smoker are given in Table 3 for the two cigarettes studied. The levels of solanesol in the delivered smoke were calculated from the level of solanesol measured in the $1 \mathrm{~cm}$ cut section of the cigarette butts of each smoker (average from three cigarettes), and are given in Table 4.

From Table 3 and 4 it was possible to calculate using Eqn. [1] the amount of solanesol retained by each smoker. The results are shown in Table 5. A positive correlation exists between the levels of solanesol retained by individual smokers from the control and from the test cigarette (the equation for the linear dependence is $y=0.9140 x+$ 14.9280 with $R^{2}=0.7836$ ). A paired $t$-test was considered appropriate to compare the control versus the test cigarettes, and determined if they show any difference. The
Table 5. The amount of solanesol in $\mu \mathrm{g} / \mathrm{cig}$ retained by different smokers (Control: no additives, $0.19 \%$ glycerin; Test same blend as Control with $2.3 \%$ glycerin)

\begin{tabular}{l|c|c}
\hline Smoker & $\begin{array}{c}\text { Control } \\
\mu g / \text { cig }\end{array}$ & $\begin{array}{c}\text { Test } \\
\mu \mathrm{g} / \mathrm{cig}\end{array}$ \\
\hline 1 & 284.6 & 290.3 \\
2 & 274.8 & 299.7 \\
3 & 319.2 & 312.8 \\
4 & 394.7 & 390.5 \\
5 & 242.7 & 245.1 \\
6 & 278.1 & 297.6 \\
7 & 321.5 & 314.4 \\
8 & 398.8 & 392.1 \\
9 & 233.2 & 204.1 \\
10 & 353.5 & 341.5 \\
11 & 277.6 & 204.3 \\
12 & 398.6 & 339.3 \\
Average & 314.8 & 302.6 \\
RSD\% & 18.9 & 20.3 \\
Min. & 233.2 & 204.1 \\
Max. & 398.8 & 392.1 \\
\hline
\end{tabular}

Table 6. The retention $\%$ of solanesol by different smokers (Control: no additives, $0.19 \%$ glycerin; Test same blend as Control with $2.3 \%$ glycerin)

\begin{tabular}{l|c|c}
\hline Smoker & $\begin{array}{c}\text { Control } \\
(\%)\end{array}$ & $\begin{array}{c}\text { Test } \\
(\%)\end{array}$ \\
\hline 1 & 66.5 & 66.8 \\
2 & 76.4 & 78.5 \\
3 & 66.3 & 66.5 \\
4 & 68.6 & 70.3 \\
5 & 62.8 & 62.9 \\
6 & 76.6 & 78.4 \\
7 & 66.5 & 66.7 \\
8 & 68.8 & 70.2 \\
9 & 60.2 & 58.8 \\
10 & 77.5 & 77.3 \\
11 & 64.1 & 58.7 \\
12 & 80.5 & 77.2 \\
Average & 69.5 & 69.4 \\
RSD\% & 9.4 & 10.5 \\
Min. & 60.2 & 58.7 \\
Max. & 80.5 & 78.5 \\
\hline
\end{tabular}

$P$ (two tail) value generated from the data was 0.1764 $(>0.05)$ showing no significant difference between the two cigarettes. It was concluded that the amount of solanesol retained was basically the same for the commercial control cigarette and for the test cigarette with $2.3 \%$ added glycerin.

The solanesol retention $\%$ for the two cigarettes calculated using Eqn. [2] is given in Table 6.

As seen from this table, the values of retention $\%$ for the control no additives cigarette varied between $60 \%$ and $81 \%$ from smoker to smoker, and between $59 \%$ and $79 \%$ for the test cigarette with $2.3 \%$ added glycerin. The average values for retention $\%$ were very close between the two evaluated cigarettes, with $69.5 \%$ for the control cigarette and $69.4 \%$ for the test cigarette with $2.3 \%$ glycerin. A strong positive correlation exists between the \% solanesol retained by individual smokers from the control and from the test cigarette (the equation for the linear dependence is $y=$ $1.0562 x-4.0878$ with $R^{2}=0.906$ ). The $P$ (two tail) value 


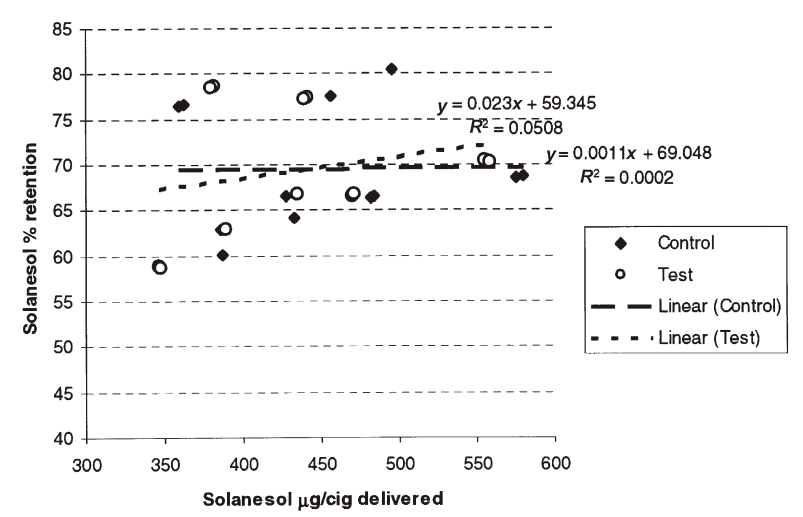

Figure 2. Graph showing the correlation between the amount of solanesol delivered $(\mu \mathrm{g} / \mathrm{cig})$ and the retention \% by each smoker

generated from the data was $0.7849(>0.05)$ showing no significant difference between the two cigarettes. It was concluded that the retention \% of solanesol was basically the same for the commercial control cigarette and for the test cigarette with $2.3 \%$ added glycerin.

The evaluation of a relationship between the amount of solanesol delivered to the smoker and the corresponding retention $\%$ showed practically no correlation. The graph of the dependence between the amount of solanesol delivered $(\mu \mathrm{g} / \mathrm{cig}$ ) and the retention $\%$ by each smoker is given in Figure 2. As seen from this figure, the trend lines for the data show an $R^{2}=0.0002$ for the control and $R^{2}=0.0508$ for the test cigarettes, with very small values for the slope of dependence. This indicated that in the range of cigarette deliveries evaluated in this study, there is virtually no correlation between the amount of solanesol delivered and the retention rate of this compound.

\section{CONCLUSIONS}

This study reports the level of solanesol in exhaled cigarette smoke for two cigarettes with identical blends, one a no additive blend with $0.19 \%$ analyzed glycerin and the other with $2.3 \%$ added glycerin. The amount of solanesol and the retention $\%$ of solanesol from the two cigarettes were not significantly different as shown using the paired t-test of the data. The retention \% of solanesol from the commercial no additives cigarette showed an average of $69.5 \%$ with $9.4 \%$ relative standard deviation, and an average retention of $69.4 \%$ with $10.5 \%$ relative standard deviation for the cigarette with $2.3 \%$ added glycerin. The study showed that the addition of $2.3 \%$ glycerin, which is in the range of this humectant level on tobacco for several commercial cigarette brands, has no influence in the solanesol retention compared to the commercial no additives cigarette.

\section{REFERENCES}

1. Baker, R.R. and M. Dixon: The retention of tobacco smoke constituents in the human respiratory tract; Inhalation Toxicol. 18 (2006) 255-294.

2. Ogden, M.W. and K.C. Maiolo: Collection and determination of solanesol as a tracer of environmental tobacco smoke in indoor air; Environ. Sci. Technol. 23 (1989) 1148-1154.

3. Tang, H., G. Richards, C.L. Benner, J.P. Touminen, M.L. Lee, E.A. Lewis, L.D. Hansen, and D.J. Eatough: Solanesol, a tracer for environmental tobacco smoke particles; Environ. Sci. Technol. 24 (1990) 848-852.

4. McAughey, J.J., D.A. Knight, A. Black, and C.J. Dickens: Environmental tobacco smoke retention in humans from measurements of exhaled smoke composition; Inhalation Toxicol. 6 (1994) 615-631.

5. Armitage, A.K., M. Dixon, B.E. Frost, D.C. Mariner, and N.M. Sinclair: The effect of inhalation volume and breath-hold duration on the retention of nicotine and solanesol in the human respiratory tract and on subsequent plasma nicotine concentrations during cigarette smoking; Beitr. Tabakforsch. Int. 21 (2004) 240-249.

6. Armitage, A.K., M. Dixon, B.E. Frost, D.C. Mariner, and N.M. Sinclair: The effect of tobacco blend additives on the retention of nicotine and solanesol in the human respiratory tract and on subsequent plasma nicotine concentrations during cigarette smoking; Chem. Res. Toxicol. 17 (2004) 537-544.

7. Moldoveanu, S.C., W. Coleman III: A pilot study to assess solanesol levels in exhaled cigarette smoke; Beitr. Tabakforsch. Int. 23 (2009) 234-240.

8. Mullard, G., P. Biggs, and D.C. Mariner: The effects of mouth-hold time and controlled inhalation depth on measured tobacco smoke retention in human cigarette smoking; Meeting of the Aerosol Soc. and Lung Modelling, Sheffield, U.K, 2004.

9. Sinclair, N.M., B.E. Frost, and D.C. Mariner: Factors related to nicotine physio-chemistry and retention in human smokers; CORESTA Congress, 1998, Brighton, U.K. Abstr. ST19, p 167.

10. Bernstein D.M.: A review of the influence of particle size, puff volume, and inhalation pattern on the deposition of cigarette smoke particles in the respiratory tract; Inhal. Toxicol. 16 (2004) 675-689.

11. Robinson, R.J. and C.P. Yu: Theoretical analysis of hygroscopic growth rate of mainstream and sidestream cigarette smoke particles in the human respiratory tract; Aerosol Sci. Technol. 28 (1998) 21-32.

12. Cinkotai, F.F.: The growth of cigarette smoke particles suspended on fine platinum wire in moist air; Beitr. Tabakforsch. 4 (1968) 189-195.

13. Moldoveanu, S.C., W.M. Coleman III: The influence of a humectant on the retention by humans of solanesol from cigarette smoke (Part 1, Propylene Glycol); Beitr. Tabakforsch. Int. 23 (2008) 153-159.

14. Bodnar, J.A., T.J. Collins, S.M. DeBusk, and M.F. Borgerding: Estimation of 'tar' and nicotine yields from individual cigarettes based on filter analysis after smoking; 58 ${ }^{\text {th }}$ Tobacco Science Research Conference, Program Booklet and Abstracts, Vol. 58, Paper No. 8, 2004, p 25.

15. St.Charles, F.K.: A robust method for determining consumer smoked cigarette yields from filter analytical data; 55 ${ }^{\text {th }}$ Tobacco Science Research Conference, Program Booklet and Abstracts, Vol. 55, Paper No. 92, 2001, pp. 73-74.

16. Moldoveanu, S., W. Coleman III, and J. Wilkins: Determination of carbonyl compounds in exhaled 
cigarette smoke; Beitr. Tabakforsch. Int. 22 (2007) 346-357.

17. Feng, S., S.E. Plunkett, K. Lam, S. Kapur, R. Muhammad, Y. Jin, M. Zimmermann, P. Mendes, R. Kinser, and H.J. Roethig: A new method for estimating the retention of selected smoke constituents in the respiratory tract of smokers during cigarette smoking; Inhal. Toxicol. 19 (2006) 169-179.
Corresponding author:

Serban C. Moldoveanu R.J. Reynolds Tobacco Co. 950 Reynolds Blvd.,

Winston-Salem, NC 27105

USA

E-mail: MoldovS@RJRT.com 